\title{
FIELD PROBLEMS OF RADIOCARBON DATING IN TASMANIA
}

\author{
by Eric A. Colhoun
}

(with two tables and one text-figure)

COLHOUN, E.A., 1986 (12:ix): Field problems of radiocarbon dating in Tasmania. Pap. Proc. R. Soc. Tasm. 120: 1-6. https://doi.org/10.26749/rstpp.120.1 ISSN 0080-4703. University of Newcastle, Newcastle, N.S.W., Australia, formerly University of Tasmania.

Radiocarbon dating of Late Quaternary deposits has shown that erosion of old organic materials and their redeposition in younger sediments may give ages that are too old. Also, the humid climate and leaching pedogenic environment of much of Tasmania permitstranslocation of young humic acids down profile through porous sediments. The humic acids may then be perched by impermeable clay horizons or may be adsorbed/absorbed by older clay and organic materials to give ages that are too young. These problems are illustrated by examples.

Key Words: radiocarbon, redeposition, translocation, humic acids.

\section{INTRODUCTION}

During the last thirty years radiocarbon dating has proved to be the most reliable method of dating sequences of Late Quaternary deposits in Tasmania. Errors in radiocarbon dating can be divided into: those related to laboratory processing and the technical limitations of the method, and those related to the judgement of the field scientist and the environmental conditions of the region or site from which the samples have been collected.

Since no radiocarbon dating facilities exist in Tasmania, field scientists depend on mainland Australian laboratories (Mackintosh Centre for Quaternary Dating, University of Sydney; and Radiocarbon Laboratory, Research School of Pacific Studies, Australian National University) or on overseas laboratories for analyses of organic samples. However, the field scientist must have a good understanding of the environmental conditions that have affected the sample before, during and after its deposition until the time of its collection and submission for analysis.

Experience in Tasmania has shown that there are a number of problems, related mainly to climate and environment of deposition, that occur frequently enough to make it worthwhile alerting those likely to use the method in the future. The probiems will be illustrated with examples listed in Radiocarbon Dates for Tasmania, 1956-1984 (Colhoun 1985a). Although the discussion will demonstrate the need for caution in field sampling and in interpreting the results of radiocarbon dating, it does not invalidate the usefulness of the technique. Radiocarbon dating is likely to remain the most significant method for assessing the age of organic deposits back to $40000 \mathrm{yr} \mathrm{BP}$ in archaeological (see Stockton 1981), geomorphological and palynological research for some decades. The discussion will not qualify all dates in the list, the details of which are either indicated in the publications or available from the authorities cited.

\section{DISCUSSION}

The problems encountered in a nalysing field sections that contain organic deposits result from the inclusion of older organic materials in younger deposits, and from the contamination of older organic materials by younger organic carbon. In the prevailing cool humid and perhumid climate of western Tasmania (Gentilli 1972) the first problem is mainly a physical one caused largely by erosion of old deposits and soil profiles from the landscape and their partial inclusion in young deposits. The second problem is mainly chemical and biochemical. It is related to the partial decay of organic materials, the leaching of humates through inorganic materials, the adsorption of humic acids by clays, and the adsorption/absorption of humic acids by old organic materials.

The problem of inclusion of old materials in young deposits has occurred for marine shells, wood, charcoal and soil organic matter. The problem with marine shells was first suspected when shells from beach sand underlying a dune at The Jam near Smithton (fig. 1) were submitted by N. Stephens to Gakushuin University Radiocarbon Laboratory and assayed at $22700 \pm 1100 \mathrm{yr} \mathrm{BP}$ (Gak 652) (Kigoshi \& Kobayashi 1966). The assay was considered to indicate that the shells were probably of interglacial age and that the age was 


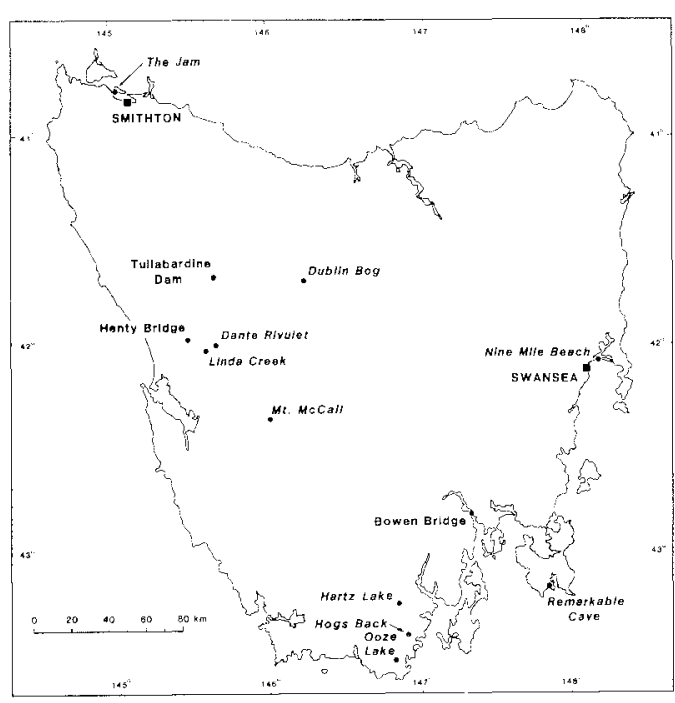

FIG.1 - Locality map.

near the limit of dating carbonate material at the time (Stephens, pers. comm.). Observations of the marine plains and shallow offshore banks west of Smithton by van de Geer (1981) showed that the Holocene transgression croded interglacial marine deposits and redeposited them. Thus, shells derived from the interglacial deposits would be included with Holocene age shells in mixed-age assemblages. Samples of shell from the base of Holocene marine sequences on gently shelving coasts could, therefore, produce age assays that may not indicate whether the deposits are of interglacial or Holocene age.

Drilling and sampling of the Holocene Nine Mile Beach barrier system north of Swansea in eastern Tasmania by Thom et al. (1981, pp.19-20) has mainly given conventional ${ }^{14} \mathrm{C}$ ages of between $8130 \pm 110 \mathrm{yr} \mathrm{BP}($ SUA 1296$)$ and $10900 \pm 130 \mathrm{yr}$ BP (SUA 1 293) for shell hash samples. These assays on samples that occur between $=1$ and $-2 \mathrm{~m}$ from m.s.l. cannot be taken as the ages of marine sedimentation by the Holocene sea, which to judge from the envelope of relative sea levels for eastern Australia (Thom \& Roy 1983) had maximum altitudes of between -8 and $-45 \mathrm{~m}$ during this time. Only one assay of $5310 \pm 90 \mathrm{yr}$ BP (SUA 1291 ) falls within the expected time range of $7000 \mathrm{yr} B P$ for deposits within $3 \mathrm{~m}$ of modern m.s.l. This sample was nearest the seaward margin of the barrier. It seems clear that shells of interglacial age have been incorporated within the samples, a problem that has been encountered in the dating of shelly marine deposits elsewhere in southeastern Australia (Donner \& Jungner 1981).

At Ooze Lake in southern Tasmania a ${ }^{14} \mathrm{C}$ age of $17700 \pm 400 \mathrm{yr}$ BP (SUA I 359) has been obtained from charcoal and finely divided organic material in a core of lake clay between 6.40 and 6.65 $m$ depth (table 1). This age is by far the oldest date in Tasmania for the apparent deglaciation of high altitude $(900-1100 \mathrm{~m})$ cirque basins that were occupied by ice during the last glaciation. Dates obtained from the basal sediments or from the lowest organic sediments in other cirque and rock basins in central and western Tasmania are between 13000 and $9000 \mathrm{yr} \mathrm{BP}$. At lower altitudes a basal date of $13400 \pm 600 \mathrm{yr}$ BP (SUA 2 188) has been obtained from lake sediments behind the end moraine at Dublin Bog $(600 \mathrm{~m})$ in the Mersey Valley. These dates compare with the date of 12590 \pm 230 yr BP(SUA 1 943) from 5.50 to $5.70 \mathrm{~m}$ depth at Ooze Lake (Macphail \& Colhoun 1985, Colhoun 1985a, Macphail \& Peterson 1975). The question of whether or not the basal date of $17700 \mathrm{yr}$ BP really represents very early deglaciation in eastern Tasmania cannot yet be fully answered. The date, however, seems extremely early since there is evidence for ice being near its last glaciation limit in western Tasmania at Dante Rivulet at $18800 \pm$ 500 yr BP (ANU 2 533) (Kiernan 1983, Colhoun $1985 \mathrm{~b}$ ), and in the Mersey Valley slightly before 13400 yr BP as indicated. The possibility that the date 17700 уг BP does not represent the age of deglaciation must be considered.

Most Tasmanian Late Pleistocene-Holocene lake core sequences consist largely of inorganic grey silts and clays overlain by organic detritus and muds. The former generally represent erosion of an alpine or poorly vegetated environment and are usually deposited quite rapidly (c.f. $3-4 \mathrm{~mm} / \mathrm{yr}^{-1}$ at Dublin Bog; $1.4-3.6 \mathrm{~mm} / \mathrm{yr}{ }^{1}$ at Ooze Lake) whereas the organic detritus/mud generally represents deposition in a well vegetated, shrub or forest environment and is quite slow (c.f. $0.3-0.6 \mathrm{~mm} / \mathrm{yr}^{-1}$ at Dublin Bog). However, deposition rates can be quite variable for short periods in any core due to local conditions. The rate of $0.2 \mathrm{~mm} / \mathrm{yr}^{-1}$ between 12.6 and $17.7 \mathrm{ka}$, at Ooze Lake in extremely low for Late Pleistocene lake clays which usually exceed 1 $\mathrm{mm} / \mathrm{yr}^{-1}$

An abundance of pollen of Lagarostrobos franklinii and significant pollen of Nothofagus cunninghamii and Phyllocladus aspleniifolizes occur during the earlier part of this time period and could suggest forest conditions likely to give low yields of sediment to lakes. However, the pollen seems mainly to have been transported from adjacent 
TABLE 1

Age and Sedimentation Rates of Two Post-glacial Sequences in Tasmania

\begin{tabular}{|c|c|c|c|c|c|}
\hline \multicolumn{3}{|c|}{ Ooze Lake, altitude $880 \mathrm{~m}$} & \multicolumn{3}{|c|}{ Dublin Bog, altitude $600 \mathrm{~m}$} \\
\hline $\begin{array}{c}\text { Depth } \\
\text { (m) }\end{array}$ & $\begin{array}{l}\text { Age } \\
\text { (ka) }\end{array}$ & $\begin{array}{c}\text { Sedimentation } \\
\text { rate } \\
\left(\mathbf{m m} / \mathbf{y r}^{-1}\right)\end{array}$ & $\begin{array}{c}\text { Depth } \\
\text { (m) }\end{array}$ & $\begin{array}{l}\text { Age } \\
\text { (ka) }\end{array}$ & $\begin{array}{c}\text { Sedimentation } \\
\text { rate } \\
\left(\mathrm{mm} / \mathrm{yr}^{-1}\right)\end{array}$ \\
\hline $0-1.1$ & 5.4 & 0.2 & $0-2.2$ & 4.4 & 0.5 \\
\hline $1.1-2.1$ & 8.9 & 0.3 & $2.2-3.2$ & 7.3 & 0.3 \\
\hline $2.1-3.1$ & 10.4 & 0.7 & $3.2-4.2$ & 8.9 & 0.6 \\
\hline $3.1-4.1$ & 10.7 & 3.6 & $4.2-5.2$ & 10.7 & 0.6 \\
\hline $4.1-4.9$ & 12.1 & 0.6 & $5.2-6.3$ & 11.7 & 1.1 \\
\hline $4.9-5.6$ & 12.6 & 1.4 & $6.3-6.8$ & 12.9 & 0.4 \\
\hline $5.6-6.6$ & 17.7 & 0.2 & $7.5-8.5$ & 13.4 & 4.0 \\
\hline
\end{tabular}

lowland sources (Macphail \& Colhoun 1985). In the later part of the period pollen indicates that grasses, composites and sclerophyll shrubs were locally important, with Casuarina and chenopod pollen being transported to the site from external sources. The local vegetation appears to have been alpine heath which is unlikely to have reduced erosion to very low rates.

Counts of charcoal particles of $>20 \mu \mathrm{m}$ diameter indicate that they are two to three times more abundant below $5.8 \mathrm{~m}$ in the Ooze Lake core than above that depth. It is hard to envisage how so much charcoal could occur in this situation unless there was either abundant burning or relatively rapid erosion of a soil surface that contained significant quantities of charcoal. If abundant burning occurred it is likely that sedimentation rates would have been high which is not consistent with the data. If erosion of soil material bearing stored charcoal from the adjacent slopes into a newly available site for deposition had occurred on deglaciation, the basal date obtained from the core could precede the age of deglaciation. Though it is impossible to conclude with certainty that this happened in the manner stated, nevertheless, distinct charcoal-rich horizons occur in the basal parts of many Late Pleistocene-Holocene cores and the likelihood of such horizons containing old charcoal is high.

The problem of sediments containing old charcoal is k own elsewhere. It is well illustrated in the MacDonald River of New South Wales where the modern flotation load of charcoal has been shown to vary in age between about 650 and 1550 yr BP depending on particle size (Blong \& Gillespie 1978). The larger particles are younger and the smaller particles are older. This is an expected result of gradual refinement of size during transport and deposition.

TABLE 2

Radiocarbon-dated Sediments at Tullabardine Dam, Tasmania.

\begin{tabular}{llcc}
\hline Depth $(\mathbf{m})$ & \multicolumn{1}{c}{ Material } & Age (yr BP) & Lab. No. \\
$0.60-0.65$ & Wood & $440 \pm 60$ & SUA 2 279 \\
1.20 & Peat & $8030 \pm 110$ & SUA 2 185 \\
1.35 & Peat & $11060 \pm 210$ & SUA 2 186 \\
1.60 & Wood & $11660 \pm 150$ & SUA 1044 \\
$1.90-2.10$ & Organic soil & $21250 \pm 270$ & SUA 1045 \\
2.50 & Trace organic carbon & $10730 \pm 660$ & ANU 4 816 \\
$3.05-3.10$ & Wood & $31500 \pm 900$ & SUA 1046 \\
2.80 & Wood & $>43800$ & SUA 1047 \\
\hline
\end{tabular}


The erosion of old wood fragments and their deposition within younger sediments is known from Henty Bridge in western Tasmania where a section through a former small lake-basin shows slope deposits overlying and interdigitating with organic clays that rest on till (see fig. 2 in Colhoun 1985c). The radiocarbon dates on orga nic mud and wood from the centre of the lake basin produced an acceptable way-up sequence of ages from $>34600$ yr BP (Gak 5595) to $<23640 \pm 1030$ yr BP (Gak 5597) for the deposits. However, where the slope deposits were interstratified with the organic clays near the margin of the lake the radiocarbon assays on wood fragments were inverted with a sample dated to $23860+890$ yr BP (Gak 5 594) underlying deposits with a sample dated to $>34190 \mathrm{yr} \mathrm{BP}$ (Gak 6 296).

The inversion of ages can be interpreted as resulting from destruction of a soil profile bearing wood fragments. The surface debris and youngest wood would be eroded and redeposited before the more deeply buried older wood. In the humid regions of western Tasmania, a standing rootstock of Telopea truncata at $0.5 \mathrm{~m}$ depth in peat at Hogsback has an age of $750 \pm 60$ yr BP (SUA 2110 ), and partly buried Athrotaxis wood at Mount McCall has an age of $2740 \pm 60 \mathrm{yr} B P$ (SUA 2 108) (F. Podger, pers. comm., see Colhoun 1985a). It seems likely that derived fragments of older wood will be encountered in numerous deposits.

The problem of young sediments giving apparently old radiocarbon ages is illustrated not only by derived shell, charcoal and wood but also by erosion of organic matter from the A horizons of soils. Study of estuarine sediments at Bowen Bridge on the Derwent River showed that the Late Holocene (4 500-0 yr BP) clays were extremely rich in colloidal organic matter $(10-22.5 \%)$. These clays were deposited by salt-water flocculation of suspended river sediments. The clays include sparse lamellibranchs throughout their $26 \mathrm{~m}$ thickness. Radiocarbon dating showed a lack of correlation between assays made on samples of shell and organic mud. Samples from the same horizon $(-29.5 \mathrm{~m}$ below sea level) differed by as much as 2930 yr (shell $4440 \pm 150$ yr BP, SUA l 964; organic mud $7370 \pm 140 \mathrm{yr}$ BP, SUA 1965 ) and a sample of organic mud from $-19 \mathrm{~m}$ was assayed as $1020 \mathrm{yr} B P$ older than a shell sample from $-26.3 \mathrm{~m}$ (mud $3080 \pm 80$ yr BP, SU A 1 962; shell $2060 \pm 150$ yr BP, SUA 1 963).

Although currents on the bed of the estuary might have been responsible for erosion and redeposition of the organic muds, it is to be expected that they would also be capable of eroding and redepositing the shell materials. The shells found within the muds showed no evidence of abrasion, which seemed to indicate that once deposited they remained there while the estuarine clays accumulated at average rates of $8-12 \mathrm{~m}$ (uncompacted sediment; 5-8 m compacted) per $\mathrm{ka}$. This indicate's that the younger radiocarbon dates obtained from the shells give the age of deposition. It also points to the colloidal humate in the muds being derived, along with abundant charcoal fragments, from soil organic materials in local catchments where the vegetation was frequently burnt by aborigines after 6000 to $5000 \mathrm{yr}$ BP (Colhoun \& Moon 1984). The second major cause of error in radiocarbon dates arises from the contamination of old organic material by young organic carbon, mainly as humic acids which drain through porous sediments but accumulate if the deposits are impermeable. Samples usually can be pretreated to remove contaminant humic acid. However, with small samples of finely divided organic matter pretreatment may sometimes not be practical. In such cases the presence of humic acids may result in a date being obtained that is considerably younger than the age of the sample. In the wet leaching pedogenic environments of southern, central and western Tasmania, samples are known to have been contaminated by (a) the perching of young humic acid at the base of a core by impermeable materials, (b) the perching of young humic acid within a section by an impermeable horizon, (c) the adsorption/absorption of young humic acid by clay/charcoal, and (d) the absorption of young humic acid by wood. Examples of these are discussed below.

A $1.9 \mathrm{~m}$ core of peat and clay deposits, extracted from a small lake that overlies till and is adjacent to Hartz Lake at $950 \mathrm{~m}$ altitude in southeastern Tasmania, gave an age sequence of $2930 \pm 100 \mathrm{yr}$ BP (SUA I 357), $4100 \pm 200 \mathrm{yr}$ BP (SUA 1944 ) and modern (SUA 1945 ) for depths of $0.5-0.59 \mathrm{~m}, 0.71-0.9 \mathrm{~m}$, and $1.6-1.89 \mathrm{~m}$ respectively (Colhoun 1985a).

Pollen analysis of the core shows that the sediment commenced accumulating during the Late Pleistocene and that deposition was probably continuous during the Holocene. However, the radiocarbon assays show that the basal sample was contaminated by modern humic acids that were perched by the subjacent till and adsorbed/absorbed on the clays/finely divided charcoal near the base of the core. The implications of the draining of humic acids through the sediments is that organic samples from higher levels may also contain some young humic acid that will give 
assays less than the age of the sediments

In the natural temperate rainforest environment at Tullabardine Dam in western Tasmania a sequence of $4 \mathrm{~m}$ of peat and lake sediments gave a dated pollen sequence that is consistent with expected ages for an interstadial, maximum lastglaciation and Holocene vegetation history (table 2), except for the assay of $10730 \pm 660 \mathrm{yr} \mathrm{BP}$ at 2.5 m (Colhoun \& van de Geer, unpublished). Only very small a mounts of organic carbon were obtained from this sample. The result suggests contamination by young humic acids that were probably perched by the silty clays and adsorbed/absorbed by the clay and finely divided organic matter.

Why the other samples should appear to give reasonable age estimates and this sa mple appear to be strongly contaminated is not clear. It may be related to the ratio of contaminant humic acid being high in the small sample whereas the same a mounts would have much less effect in the larger samples, even though the dates would provide younger than real ages. However, the age difference could also wholly or partly have been caused by young humic acids translocated through the peat, buried soil and mineral horizons being perched by the impermeable silty clay. Perching within sequences by impermeable beds seems as likely as basal concentration by underlying materials.

In addition to the perching of humic acids near the base or within sediment sequences, humic acids may be directly adsorbed onto or absorbed into organic matter and may not be removed completely by pretreatment, especially if only hydrochloric acid is used.

At Remarkable Cave in southeastern Tasmania charcoal fragments from the base of $17 \mathrm{~m}$ of slope, gully-fill and cliff-fall deposits overlying an interglacial beach were assayed at $29000 \pm 2000 \mathrm{yr}$ BP (SUA 154). In an attempt to date higher levels in the deposits, five samples of wood and peaty organic materials were assayed and all were found to have ages greater than $37000 \mathrm{yr} \mathrm{BP}$. The higher samples all received acid-alkali-acid pretreatment which largely removed the humic acids from the wood and peaty materials but the first sample (SUA 154) did not receive alkali pretreatment before assay. The charcoal had been contaminated by younger humic acids (Colhoun 1977). The results indicate that if the charcoal sample alone had been assayed after acid pretreatment, the interpreted age of the deposits would not have been correct.

A similar, though more complex, problem was encountered with attempting to date the classic glacial site in the Linda Valley of western Tasmania.
Here, till and sandy ice-marginal glacigenic deposits overlie an ancient soil with standing tree stumps that include Phyllocladus. An early ${ }^{14} \mathrm{C}$ date of $26480 \pm 800 \mathrm{yr}$ BP (W 323) (Gill 1956) determined on a piece of wood derived from the soil but bedded within the glacial deposits suggested that this represented the age of the last glaciation maximum. An unpublished date of $>40000 \mathrm{yr} B P(R$ 488) on wood from a Phyllocladus stump in the soil (M.R. Banks, pers. comm.) cast doubt on the younger result and suggested a contamination problem. In an attempt to resolve the problem, both a wholewood sample and its -cellulose fraction (the supposedly most stable fraction) were dated at $27800 \pm$ $700 \mathrm{yr} B P(\mathrm{ANU} 2480 \mathrm{~A}$ ) and $23100 \pm 600 \mathrm{yr} \mathrm{BP}$ (ANU $2480 \mathrm{~B}$ ) respectively, and the apparent contamination problem remained. Further dating of large wood-samples from the palaeosol has given an assay of $>48500 \mathrm{yr}$ BP (ANU 3413 ), but the stratigraphy, the glacial deposits, reversed magnetisation of associated glacial lake clays, and pollen of Tertiary-type in the buried soil all pointed to an Early Pleistocene or older age (Colhoun 1985b).

In an attempt to ascertain how the wood was contaminated, the ${ }^{13} \mathrm{C} /{ }^{12} \mathrm{C}$ values were determined using PDB as standard. The whole-wood gave a $\delta^{13} \mathrm{C}$ value of $-15^{\circ} / \mathrm{oo}$ and the $\alpha$-cellulose values of -20 to $-22 \%$ oo. Both values are more positive than the typical $\alpha^{13} \mathrm{C}$ values for wood of -25 to $-34 \% / 0$, and -22 to -23 o o o for $\alpha$-cellulose (Smith \& Epstein 1972, Head, pers. comm.). The positive shift in the $\alpha$-cellulose fraction is so small that it cannot be regarded as significant. However, the positive shift for the whole-wood sample is large and lies within the -11 to $-16 \%$ oo range typical for monocot yledons such as Gramineae and Cyperaceae. Why the apparent age of the $\alpha$-cellulose fraction should be younger than the other age determinations is not known. The strong positive shift of the $\delta^{13} \mathrm{C}$ value given by the whole-wood sample strongly suggests contamination by younger humic acids derived from a monocotyled onous acidic vegetation type. Pollen data indicate that during the last glaciation much of the area was grassland, heathland and sedgeland for considerable periods.

The above examples demonstrate that in the humid environments of Tasmania, with their acid vegetation communities and leached soil profiles, young humic acids may contaminate old samples of organic matter, charcoal and wood, and that ${ }^{14} \mathrm{C}$ assays cannot necessarily be accepted as indicating ages without knowing the detailed stratigraphy of the site and the methods of sample pretreatment. The examples also indicate that it is unwise to 
conclude the age of any deposit from the assay of a single sample. It seems necessary to obtain, wherever possible, several samples from different levels in clearly defined stratigraphic successions and if consistent age sequences are not obtained from whole-wood or extract samples then chemically fractionated samples should be dated.

\section{ACKNOWLEDGEMENTS}

I thank the ARGC and the University of Tasmania for providing research funds for radiocarbon dating. I also thank Mike Barbetti and Richard Gillespie of University of Sydney, and Henry Polach and John Head of the Australian National University for technical guidance and comments on the ${ }^{14} \mathrm{C}$ analyses. I would also like to thank Miss Ifay Tsang and Miss Sally Banks for typing the manuscript.

\section{REFERENCES}

BLONG, R.J. \& GILLESPIE, R., 1978: Fluvially transported charcoal gives erroneous ${ }^{14} \mathrm{C}$ ages for recent deposits. Nature 271: 739-741.

COLHOUN, E.A., 1977: The Remarkable Cave, southeastern Tasmania: its geomorphological development and environmental history. Pap. Proc. $R$. Soc. Tasm. 111: 29-39.

COLhoun, E.A., 1985a: Radiocarbon dates for Tasmania 1956-1984. Pap. Proc. R. Soc. Tasm. 119: 39-54.

COLHOUN, E.A., 1985b: Glaciations of the West Coast Range, Tasmania. Quaternary Research 24: $39-59$.

COLHOUN, E.A., 1985c: Pre-last glaciation maximum vegetation history at Henty Bridge, western Tasmania. New Phytologist 100: 681-690.

COLHOUN, E.A. \& MOON, A., 1984: Estuarine sediments at the Bowen Bridge on the Derwent River, southeastern Tasmania. Search 15 (7-8): 224-226.

COLHOUN, E.A. \& VAN DE GEER, G., in press: Holocene to middle last glaciation vegetation history at Tullabardine Dam, western Tasmania. Proc. R. Soc. Lond.
DONNER, J. \& JUNGNER, H., 1981: Radiocarbon dating of marine shells from southeast Australia as a means of dating relative sea-level changes. Ann. Academae Scient. Fennicae, Series AIII Geol.-Geogr. 131: 44pp.

GENTILLI, J., 1972: AUSTRALIAN CLIMATIC PATTERNS. Nelson, Melbourne. 285pp.

GILL, E.D., 1956: Radioearbon dating for glacial varves in Tasmania. Aust. J. Sci. 19:80.

KIERNAN, K.W., 1983: Weathering evidence for an additional glacial stage in Tasmania. Aust. Geogr. Studies 21: 197-220.

KIGOSKI, K. \& KOBAYASHI, H., 1966: Gakushuin natural radiocarbon measurements $V$. Radiocarbon 8: 54-73.

MACPHAIL, M.K. \& COLHOUN, E.A., 1985: Late Last Glacial vegetation, climates and fire activity in southwest Tasmania. Search 16(2): 43-45.

MACPHAIL, M.K. \& PETERSON, J.A., 1975: New deglaciation dates from Tasmania. Search 6: 127-130.

SMITH, B.N. \& EPSTEIN, S., 1972: Two categories of ${ }^{13} \mathrm{C} /{ }^{12} \mathrm{C}$ ratios for higher plants. Plant Physiology 47: 380-384

STOCKTON, J., 1981: Radiocarbon dates for archaeological sites in Tasmania. Aust. Archaeology 12: $97-101$

THOM, B.G., BOWMAN, G.M., GILLESPIE, R., TEMPLE, R. \& BARBETTI, M., 1981: RADIOCARBON DATING OF HOLOCENE BEACHRIDGE SEQUENCES IN SOUTH-EAST AUSTRALIA. Monograph 11, Department of Geography, University of N.S.W., Royal Military College, Duntroon.

THOM, B.G. \& ROY, P.S., 1983: Sea level change in New South Wales over the past 15,000 years. In HOPLEY, D. (Ed.): AUSTRALIAN SEA LEVELS IN THE PAST 15,000 YEARS: A REVIEW. Occasional Paper 3, Monograph Series, Geography Department, James Cook University: 64-84.

VAN DE GEER, G, 1981: LATE QUATERNARY MARINE AND FRESHWATER SWAMP DEPOSITS OF NORTHWESTERN TAS$M A N I A$. Ph.D. thesis, University of Tasmania.

(accepted May 2, 1986) 